\title{
Entrepreneurs as decisive human resources and business performance for the Lao SMEs*
}

\author{
Sengaloun Inmyxai, Yoshi Takahashi \\ (Graduate School for International Development and Cooperation, Hiroshima University, Kagamiyama 739-8529, Japan)
}

\begin{abstract}
Resource-based view (RBV) has been a very important theory to explain performance in the past decades. Among several types of resources, human resources are known as a critical factor for business success. The present paper has sought to link the human resources and performance based on the concept of RBV focusing on entrepreneurs as decisive human resources. This paper uses a sample of $378 \mathrm{Lao}$ small and medium enterprises (SMEs). Overall, the findings suggest that the significant factors in explaining performance in Lao SMEs are the education of entrepreneurs, business development services for entrepreneurs and experience of entrepreneurs. Whereas training at starting business and training for entrepreneurs were not supported.
\end{abstract}

Key words: SMEs; human resources; human resource development; developing countries and performance

\section{Introduction}

The organization theory has explained individual human behaviors in the organization that can affect firm performance. Thompson (1967) was one of the pioneer works that explained how the human variables influence organizational actions. As knowledge of human aspect is included in human resources of the firms, it is a crucial factor for business success. The knowledge of human aspect has been a very important component for achieving a competitive advantage (Grant, 1996). Finkelstein and Hambrick (1996) emphasized on the importance of the human aspect in strategic choices and firm performance. Firms can make use of the human aspect as a basis to develop short-term and long-term strategy to match with the firms' objectives. Hambrick and Mason (1984) described the organization as a reflection of its top managers. If top managers act for the benefits of the organization, it can achieve better performance. In fact, top managers represent a unique organization of resources (Daily, et al., 1999), which can create competitive advantage over the rival firms.

Organization theory has emphasized on human behavior but it has not indented human resources of firms as strategic resources for the firms. However, resources-based view (RBV) has tried to identify the strategic resources. RBV is the important theory to explain the influential resources on firm performance and as a result, it pointed the importance of human resources. In that sense, it emphasizes the different forms of firms' resources

\footnotetext{
* We are really pleased to express our sincere gratitude to Prof. Tatsuo Kimbara and the anonymous reviewers for their insightful suggestions, we are grateful to the reviewers for their valuable comments to improve this paper. Special thanks to Germany Agency for Technical Cooperation (GTZ) that provided the secondary data. Any errors that appear in this paper is entirely the authors' responsibility.

Sengaloun Inmyxai, Ph.D. candidate, Graduate School for International Development and Cooperation, Hiroshima University; research field: management of micro, small, medium sized enterprises (firm resources and firm performance, human resources and firm performance, gender and firm performance in the Lao PDR or in the least development country context).

Yoshi Takahashi, associate professor, Graduate School for International Development and Cooperation, Hiroshima University; research fields: human resource development and management, management of small and medium sized enterprises and industrial development.
} 
that are held by firms in explaining profitability (Penrose, 1995; Wernerfelt, 1984). In discussion, resource heterogeneity is subject to what extent organizations own having different bundles of resources (Peteraf, 1993). The benefits of resource heterogeneity can be seen when some organizations have more strategic resources than others. Therefore, studies of RBV basically view that the extent to which organizations having such strategic resources is associated positively to their performances.

In SMEs, particularly in developing countries, in comparison with other members in the organizations, entrepreneurs ${ }^{1}$ are critically influential human resources who have accumulated "human capital" such as stock of knowledge and skills. The success of the firms can be derived from having very competent and skillful entrepreneurs who can manage the complex business activities and create plans for future growth. Entrepreneurs are strategic resources for the firms because they can influence the business activities of the firms both directly and indirectly through the employees by themselves. Strategic resources of the firm are critical to the competitive advantages, which in turn can influence firm performance. Strategic resources generate economic value to an organization controlling them, which can create competitive advantages because they are difficult to replicate and thus resources-based advantages can be maintained in a lifespan (Hoopes, et al., 2003). Resources that are valuable, unique and difficult to imitate can provide the competitive advantages (Admit \& Schoemaker, 1993; Barney, 1991). The competitive advantages lead to positively affect performance (Peteraf, 1993).

The objectives of this paper are to examine the influences of human resources with human capital, which expect to affect business performance in the case of Lao SMEs. The paper is divided into six sections. Section one is the introduction. Following this introduction is section two that explains the conceptual framework. Section three presents literature review and hypotheses development as well as defines the main terms in the paper. Section four describes the research methodology. Section five presents the analysis and discussion. The final section provides the conclusion and implication from the present paper.

\section{Conceptual framework}

As mentioned in the previous section, the literature has dealt with the impact of human resources on competitive advantage and consequently firm performance. Based on these discussions, the present studies will analyze particularly the impact of entrepreneurs as decisive resources on firm performance in the case of SMEs in Lao PDR.

Strictly speaking, when strategic resources such as human resources and performance are associated, competitive advantages must be present (Crook, et al., 2008). However, some prior researchers also use the term competitive advantage almost synonymous with performance, because competitive advantage is often used to explain the relative performance of competitors in a certain market condition (Peteraf \& Barney, 2003, p. 313). In addition, we face an empirical problem that competitive advantages are not easy to measure (Ketchen, et al., 2007). Therefore, previous researchers tended to link strategic resources and performance directly (Barney \& Arikan, 2001). The present paper follows such discussion and examines the relationship between human resources and performance directly.

The conceptual framework in Fig. 1 illustrates and explains the relationship between human resources and firm performance. Hence, five hypotheses are developed. Performance is the objective of the firms and thus it is

\footnotetext{
${ }^{1}$ Our definition of entrepreneurs includes both owner/managers and top managers employ from outside so that the terms of entrepreneurs and top managers are used interchangeably.
} 
treated as the dependent variable. The independent variables are human resources variables at the beginning of businesses (including education, business development services and training at starting business), human resource development after starting businesses (i.e. training for entrepreneurs), pervious experience of entrepreneurs. Firm size, firm age and training for employees are used as control variables, which are expected to influence performance. This conceptual framework is modified from the concept of human capital in the study of Hatch and Dyer (2004); The theoretical background and emerging literature reviews in related fields such as the resource-based view and human resources (Andrews, 1980; Barney, 1986a; Barney, 1991; Dierickx \& Cool, 1989; Fahy \& Smithee, 1999; Mahoney \& Pandian, 1992; Oliver, 1997; Wernefelt, 1984; Wernefelt; 1995), will be presented in the next section.

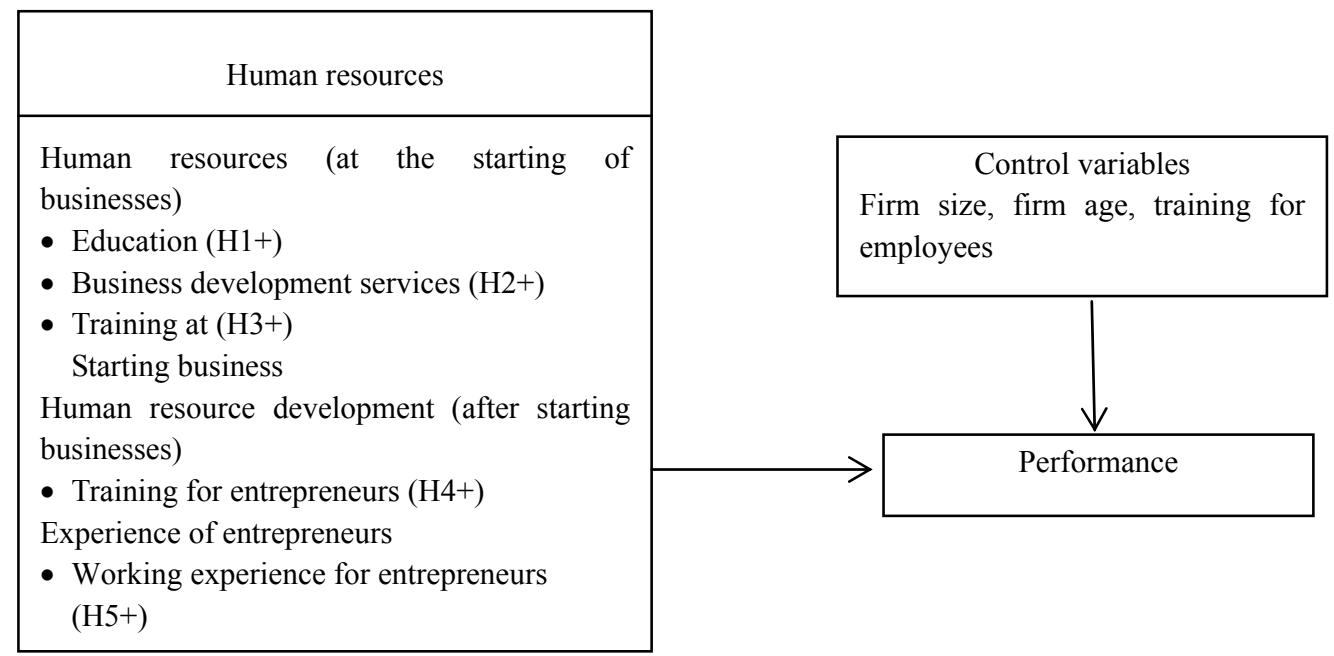

Fig. 1 Conceptual framework is modified from Hatch \& Dyer (2004)

\section{Literature review and hypotheses development}

\subsection{Human capital theory for understanding human resources}

This section is to review human capital theory because it is very useful to understand similar but different concepts of "human resources". Human resources are focusing on the quality of manpower. In measuring the quality, we need to rely on the "human capital" theory that directly deals with knowledge and skills acquired. Human resources are entrepreneurs and members in firms while human capital is more of an abstract or invisible concept, which is embodied in the human resources. Also, we are looking at the same thing from different aspects by the human resources and human capital so they cannot be separated. Although in other sections, we prefer to use "human resources" as our focus which is generally more on entrepreneurs, however in this section on human capital theory review, we use human capital in accordance with literature. Human capital has been identified in two ways: past investments or inputs from individuals and firms on education, training, experience and outputs from past investments as a result like knowledge and skills.

Human capital has been viewed as a critical resource in most firms (Pfeffer, 1994). It includes the accumulation of prior-investments in education and on-the-job-training, which can improve productivity of the firms (McConnell \& Bruc, 1995, p. 612). Other authors view human capital as the knowledge of employees and skills while human resources are employees themselves and in this definition some human capital (i.e. education) is generic whereas some is firm-specific (Hatch \& Dyer, 2004, p. 1155). Human capital is actually possessed by 
the employees in terms of know-how, trade secrets for the firm, which are not easy to be defined (Grant, 2002). These mentioned definitions of human capital seem to combine the concept of inputs or investment in human capital of individuals and firms, including education, on-the-job-training and outputs or return on investments in human capital which included skills, knowledge, know-how and trade secret that are embodied in human resources.

Cooper (1981) suggested that experience and education were "antecedents" for starting a business and ultimately impacted performance. The characteristics of human capital including education, experience and skills especially with top managers' impact outcomes (Finkelstein \& Hambrick, 1996; Huselid, 1995; Pennings, et al., 1998; Wright, et al., 1994). The notion of human capital is that people possess the skills, experience and knowledge that have the economic value to firms (Snell \& Dean, 1992).

Human capital can be obtained from firms' investments by recruiting specific individuals from the labor market. Human capital is transferable and thus it commands a price on the labor market (Parnes, 1984). Human capital represents the abilities and know-how of people that have been acquired at some costs that can represent a price in the labor market as they are useful in the production process (Parnes, 1984, p. 32). Skills and knowledge of human resources are indications of human capital that can improve productivity. Employees can increase value to firms to the extent that they can perform future services (Parnes, 1984). Some of the values are indicated in the firm's products and services to customers.

The incentive to invest in human capital for firms is based on the potential return from human capital. In short-term, increased investments in human capital can be costly to the firms and it can lead to reduce the profitability while in long-term these investments can improve the capabilities, knowledge and skills, which are necessary to improve efficiency and productivity. Investments through human resource management are justified solely if they are potential to generate future returns through improving productivity (Duncan \& Hoffman, 1981; Rumberger, 1987; Tsang, 1987). The value of human capital through investments depends on the potential of contribution from employees to the firms because firms keep investing up to the point at which marginal costs are equivalent to the marginal returns (Snell \& Dean, 1992). The higher potential for contribution of employees makes firms more likely to increase investments in the human capital (Becker, 1976; Parne, 1984).

Human capital has more freedom of transferability than physical capital. Firms do not possess the human capital, which is embodied inside the employees who are free to transfer from one firm to others (Becker, 1964; Jacoby, 1991). Firms have only legal rights from the contracts with employees but it does not guarantee that the employees will have a lifetime employment with the firms and the willingness to dedicate their knowledge and capabilities for the firms. Therefore, human resource policies are needed to motivate employees and create the sense of belonging of employees to firms. The costs of retaining and motivating employees are necessary to maintain the capable employees to stay with the firms (Flamholtz \& Lacey, 1981).

The collections of human capital in the firm depend upon the policies of the firm involved with employee selection criteria, development and deployment (Koch \& McGrath, 1996; Snell \& Dean, 1992). Selection, development and deployment of employees are a series of human resource management roles that represent an increase in human capital and firm specificity as well as increasing barrier for imitability by others (Hatch \& Dyer, 2004). Deployment of these human resources aims to achieve the objective of the firms.

The roles of human resource management can influence the competitive advantage. Firms begin by recruiting new employees from an external labor market who are qualified for the vacancy position in firms. Human capital is embodied in new employees that have not shown firm-specific and thus firms require developing such 
employees through investments in specialized human capital in order to improve their productivity and efficiency. Investments in human capital have sometimes been taken to achieve improvement to certain levels of learning in the firms. The human capital of the firms can maintain competitive advantage if the firms can prevent rivals from quickly acquiring similar value and inexpensively to obtain such human capital (Barney, 1991). Therefore, the roles of human resource management are essential for the long-term achievement in building human capital.

Moreover, human capital theory differentiates industry-specific from firm-specific human capital (Becker, 1964). Firm-specific human capital is knowledge related to unique routines and procedures that have limited value to outside the firm in which the human capital base has been developed (Pennings, et al., 1998).

RBV supports that principal heterogeneity and firm-specific routines may not allow the trained managers within one firm to be equally benefited by other firms. As the firm-specific knowledge includes both explicit and tacit knowledge received in a specific circumstance, they are not easy to be fully mobile and transfer (Hatch \& Dyer, 2004). Firms having specificity of certain human resources are evident to be the greatest factor impact on the competitive advantage (Ahoroni, 1993; Becker, 1975; Mahoney, 1992). Investment in human capital is time-consuming as the firms must be able to select human resources, develop and deploy them. If the competitors want to achieve the same level of competitive advantage, the competitors need to spend similar amount of time for investment in human capital.

Human resources with human capital refer to knowledge, skills and experiences of its entrepreneurs in the case of Lao SMEs that have accumulated through formal education, trainings and experiences. In this paper, human resources at starting business, human resource development after starting business and experience of entrepreneurs, which will be addressed in the following section.

\subsection{Human resources and performance}

Human resources are entrepreneurs and employees who have capabilities and competences that can be deployed to influence firm performance. Penrose (1995, p. 24) suggests that a firm's human resources consist of both unskilled and skilled labor, clerical, administrative, financial, legal, technical and management team. Entrepreneurs and employees are tangible resources for the organization (Penrose, 1995). However, Grant (2002) views human resources similar to intangible resources that are more likely to generate competitive advantage than other tangible resources. Human resources involve the productive services that people provide to the firm in the form of their skills, knowledge, expertise and decision-making capability for firms (Grant, 2002). In fact, human resources have not been recorded in the balance sheets of firms for two reasons: people cannot be owned by any firms, and firms only have a contract with their employees to buy their time and expertise (Grant, 2002).

Human resources possess human capital. Cappelli and Singh (1992) refer to human resources as an "actually accumulated stock of knowledge, skills and abilities that individuals possess, which are time-consuming to develop an identifiable expertise". The way these authors define the human resources are almost the same as the definition of human capital that is defined in the previous section by other authors.

As excellent talented entrepreneurs can transfer their knowledge to a team, they can provide strengthening organizational capabilities (Boxall, 1996), for example, the talented entrepreneurs consist of different types of talent such as leadership and human relations. Effective organizational activities are achieved through human resource capabilities that indicate the firm's capabilities associated with its human resources, its strategic objectives and a behavioral representing expertise (Kamoche, 1996). Expertise of entrepreneurs can be found in a behavior that is consistently advanced on the creation of skills, which become fundamental for competition (Klein, et al., 1991). 
However, Wright, et al (1994) argues that it does not guarantee that firms with above-average managers will be successful in their control of the valuable resources. Unless superior managers of firms deploy their capabilities to benefit for entire firms, firms can achieve better performance. Thus, firms with superior human resources utilization have a potential to influence on performance (Koch \& McGrath, 1996).

In addition, the above mentioned aspects of human resource factors such as education for entrepreneurs, business development services for entrepreneurs and training at starting business for entrepreneurs, which can contribute to superior performance will be discussed in the following section.

Education is one of the most popular entrepreneurial variables in previous studies. Education of entrepreneurs can impact the path to business success because this is a process of building the absorptive capacity of managers such as confidence, psychology, knowledge and skills. An absorptive capacity can also accumulate within firms as it is a function of the level of the firm's prior related knowledge; The firms' previously collected knowledge facilitates the absorption of knowledge (Danneels, 2008, p. 525). A number of previous studies suggested that years of formal education of entrepreneurs before establishing business were associated with firm performance (Box, et al., 1993; Brush \& Hisrich, 1991). Box, et al (1993) also found that there was a positively associated relationship between high education levels of entrepreneurs and performance for manufacturing firms in Oklahoma. Additionally, Yusuf (1995) reported that one of the success factors in small businesses was the education levels of the owner/managers, which can assist firms to survive and manage in a complex environment and can keep the business profitability.

Moreover, Schutjens and Wever (2000) observe that business managers who have a reasonably good education can handle complicated business activities. The collection of knowledge and prior-qualification can help improve the confidence of owner/mangers. The managers' skills and competencies are associated with business success (Casson, 1982c). Particularly important skills for entrepreneurs are capable of predicting and making decisions under conditions of uncertainty. Changes in sales value over time are attributed to only change in human performance (Steffy \& Maurer, 1988, p. 280). Therefore, specific features that can be realized from the education of entrepreneurs can have an impact on firm performance.

Hypothesis 1: Education of entrepreneurs positively affects performance.

In addition, business development services (BDS) for entrepreneurs can be obtained through professional advisors such as lawyers, bankers and accountants that aim to improve business performance, particularly to support small and medium enterprises at starting businesses. Management know-how may be also obtained through receiving professional advisors (Cooper, et al., 1994). BDS can be either free of support from government or paid support which can be obtained by firms. Business service providers can provide different forms of services including business support centers, mentoring, clusters and networks, business incubators, training, consultancy and advisory services, marketing assistance, information, technology development and transfer, and business linkage promotion, which are expected to affect the business performance (Kennedy, 2000; Tanburn, et al., 2001).

BDS consist of two types, the operational and strategic services (Tanburn, et al., 2001). Operational services are involved with routine business operations such as information and communications, management of accounts and tax records, compliance with labor laws and other regulations. Unlike strategic services, operational services are not difficult to work out the demand and willingness to pay for goods and services, which firms can base on the existent market. However, strategic services serve firms to address short-term and long-term issues in order to improve the performance of the firms through access to markets and be able to compete. Strategic services can provide a critical guidance for long-term sustainable performance for the firm because they can identify and 
service markets, design products, establish facilities and seek for sources of financing. In the long-term, markets for strategic services are a more critical factor to maintain superior performance of firms.

BDS are very important for SMEs. In least developed country such as Lao PDR not all firms can obtain BDS. Thus, the government and donors often provide BDS to firms. Firms benefit from various forms of professional assistance that has been examined in a number of studies. For strategic advice, it is taken by firms, which expect to have an impact on firm performance, for example, one of the studies is that using advice from accountants including useful advice related to strategic decision has been positively associated with performance ( $\mathrm{O}^{\prime}$ Neill \& Duker, 1986).

Hypothesis 2: Business development services for entrepreneurs positively impact performance.

Training at starting business (TSB) can help entrepreneurs to obtain specific knowledge and skills, which are necessary at the beginning of the business. This can assist entrepreneurs to have a good mindset and be ready to operate the business. With general skills and specific-knowledge, entrepreneurs can deal with issues related to uncertainty of businesses environment. TSB includes business management, accounting, marketing, laws and regulations, quality management, business finance, cost calculation, health and safety. TSB can increase developing knowledge and skills in running a business, provide valuable lessons to new firms to be aware of challenges and be better to prepare and be less disheartened when the future problems may arise. In developed countries, TSB is treated as a very important factor for improving business while in least developed countries firms tend to perceive it as additional costs to firms. This means that there are not many firms to utilize TSB. Although, the literature has not provided any empirical observation in this dimension, we hypothesize that such training can increase the readiness and confidence of entrepreneurs and as a result it can have a positive impact on performance.

Hypothesis 3: Training at starting business for entrepreneurs positively impacts performance.

\subsection{Human resource development and performance}

Human resource development (HRD) is an important strategy for sustainable superior performance of firms in the long-term for SMEs. Human resource development contains different types of training, which is actually an investment of the firm to build up the human capital. Developing human capabilities through training do not only depend upon the level of investment in human capital by the firms, but it also depends on the willingness of employees to learn new things that increase knowledge and skills, which they require to use in business activities. Therefore, there is a strong connection between investment in human resource development, and willingness and consequent comparative productivity of a firm's human capital (Koch \& McGrath, 1996, p. 340).

Entrepreneurs need off-the-job-training after starting a business as on-the-job-training tend to be seen as fragmented and not really systematic. Therefore, entrepreneurs can answer such problems by obtaining the specific training, which is in line with the objectives of firms.

Top managers who are employed from the external labor market can be riskier than managers who are in both roles, owners and managers in the SMEs. As firms lack ownership of critical human resources for a "job-hop" employment culture, there are some risks related to investments in training for top managers. Firms may lose the "secret" resources such as patents (Ghemawat, 1986). If firms train top managers through many kinds of training and then managers resign from the firms or are hired away by rivals, the firms have lost the benefits of the training and the top managers with specific and secret knowledge.

Firms also need to be careful in selecting training areas for top managers, which it should avoid being equally beneficial to competitors (Becker, 1964, p. 166). These investments in human capital can be risky for the 
firm if the training seems to be subsidized for the competitors (Becker, 1964). In the case of top managers, they leave firms to work for the competitors and thus the retention strategy needs to be in place to keep such top managers in order to avoid leaking confidential information about the firms.

Retaining strategy is required to keep key human resources such as top managers. Kamoche (1996, p. 217) suggests that retention of top managers can be achieved through rewarding systems, job security, training and career development, autonomy and fostering of a sense of belonging. Hence, firms need to treat top managers to absorb a sense of belonging to firms. Organizational cultural norms have also been asserted to be related to retention capacity (Kerr \& Slocum, 1987; Sheridan, 1992). Especially, a culture emphasizing in interpersonal relationship values is more attractive to professionals than one's work task values (Sheridan, 1992). Training and career management are also important strategies for retention (Lahteenmaki \& Paalumaki, 1993) as developing expertise is essential to the firm's core tasks.

Hatch and Dyer (2004) propose that a firm can bypass investment in human capital by stealing human resources from competitors' firms. Firms can successfully steal human resources from competitors' firms by offering better employment benefits to them but it can be argued that such human resources still require having specific-training to adjust with current firms because inheriting knowledge and skills from former firms may not fully be applicable for current firms. Therefore, current firms require spending for adjustment costs that provide specific-training to new managers. Theory of appropriate rents also suggests that the differences between first and second-best uses of human resources are used in the environment where it was originally built in human resources (Klein, et al., 1978). As an individual with firm-specific human capital transfers to other firms, an individual's accumulated knowledge is only partly applicable to the new environment (Becker, 1975).

As training is evident to influence on the performance, firms continuously invest in training to achieve better performance. Firms with accumulation of knowledge realize "strategic asset" (Winter, 1987) by learning through training that can have an impact on the production process. Training is part of the path dependency because the benefits of training have accumulated over time, which creates "bundles" of routines that are not easy to understand and imitate (Koch \& McGrath, 1996). RBV suggests that creating bundles of routines are the main driver for superior performance.

Lastly, skills and capabilities of entrepreneurs that are gained from training can improve the productivity and efficiency in firms. An underlying investment in entrepreneurs through training can upgrade their skills and capabilities, which is expected to have an impact on firm performance.

Hypothesis 4: Training for entrepreneurs positively affects performance.

\subsection{Working experience of entrepreneurs and performance}

Working experience of human resources can be derived from path dependency and past investment in human resources. The influential previous experience of entrepreneurs was also examined by several studies in the past since the previous experiences of entrepreneurs can be prevented from being imitated, which can be a source of sustainable competitive advantage, in turn, better performance for the firms. Previous experience in business is one of several factors for the success of firms (Yusuf, 1995). This experience can be specific knowledge and skills of entrepreneurs in the business. Box, et al (1993) reported that prior start-up and years of experience of entrepreneurs were significantly associated with performance in a study of 300 manufacturing firms in Tulsa (in the State of Oklahoma).

As previous experiences of entrepreneurs have accumulated specific-skills through on-the-job-training (OJT), it can prevent other firms from imitating such skills. Increasing the stock of know-how through 
on-the-job-training and "learning by doing" play crucial roles. Firm specific-skills actually develop through on-the-job-training that has been proven to be related to high economic returns (Bishop, 1991; Castanias \& Helfat, 1991). The benefits of on-the-job-training include low cost, minimal training time, immediate productivity and concurrent trial period. When basic skills are required, on-the-job-training can be the most beneficial (Snell \& Dean, 1992).

The age of entrepreneurs stands for life experience and years in practice which captures expertise (Collins-Dodd, et al., 2004), as the experience of entrepreneurs has collected through a number of past events and social complex activities. In this case, experience refers to working experience of entrepreneurs. Experience of owner/managers represents various skills and credentials ( $\mathrm{Ng}$ Wai-Kit, et al., 2007). As it is a critical ingredient of human resources in the firm, which entrepreneurs have accumulated over time in forms of knowledge and skills that can reduce the potential to allow competitions to imitate specific-knowledge and skills from such experience.

Experience has developed from past and present work that can be general and specific-knowledge and skills. Work experience in the past can be experience in management, team work, sales, cooperation and industrialization. Hatch and Dyer (2004) suggest that the value of experienced human resources cannot be imitated for some time and the dynamic adjustment costs of training and using new human resources can lead to continual differences in performance. Steiner and Solem (1988) observe that successful firms utilize the prior experience of owner/managers. Working experience in management is one of the successful factors for firms (Schutjens \& Wever, 2000). Therefore, longer experience of entrepreneurs can have a potential impact on firm performance.

Hypothesis 5: Longer experience of entrepreneurs has a positive impact on performance.

\subsection{Firm performance}

To measure firm performance, financial data is preferable but firms are not often willing to disclose the confidential financial data unless the laws require them to disclose it to the public. Hence, the subjective performance measures have been widely used in strategy related research (Dess \& Robinson, 1984; Robinson \& Pearce, 1988; Venkatraman \& Ramanujam, 1986; Spanos, 2001). This is partly because of the difficulty to obtain reliable financial data. Financial data are also criticized for being unreliable and subject to inconsistent accounting practices among the firms or even to managerial manipulation for different reasons including: to avoid paying high corporate income taxes or personal income taxes (Dess \& Robinson, 1984; Sapienza, et al., 1988; Powell \& Dent-Micallef, 1997). Therefore, subjective measures have been widely acceptable in organizational research (Lawrence \& Lorsch, 1967; Dess, 1987; Powell, 1992a; Powell \& Dent-Micallef, 1997).

\subsection{Control variables}

In order to eliminate any bias in the findings due to the differences in firm size, the length of time that businesses has been in the industries as well as training for their employees that has been invested in employees, we decided to control variables such as firm size, firm age and training for employees.

Firm size indicates the size of operation that can be a key factor that determines how firms are managed. Firm size can be substantiated to believe to be correlated with the survival of the firms (Mukhtar, 2002). The bigger firms can enjoy the economies of scale as they are able to exploit available resources than the smaller firm (Dass, 2000). Achieving economies of scale means that bigger firms can produce a larger quantity of outputs with low costs (Penrose, 1995), because they have the capacity to access the critical resources such as business finance and other resources. In turn, these can lead to a competitive advantage and better performance. Ghemawat (1986) suggests that inimitable positions are derived from size advantages that are capable of accessing resources or customers, and/or restriction on rivals' options. Firm size is also a key factor in providing access to low cost 
capital (Goerzen, 2007). The other important issue of this control variable is that we use the sales as performance indicator so that we need to control the firm size in order to avoid bias in the model. Firm size is often used as a research variable as well as a control variable but the findings are not consistent. One justification of insignificance of firm size on performance is that larger firms are less adaptive and flexible and less able to change their resource base as the majority of researchers argue (Chandy \& Tellis, 2000; Kanter, 1988).

Controlling the firm age is also important, because to some extent firm age can influence firm performance. Firstly, young firms tend to have lower sales and thus lower profits (Watson, 2002), while older firms tend to be larger in terms of sales turnover, number of employees and capital assets (Rosa, et al., 1996). Secondly, the older firms tend to build good networks with business partners and customers as well as have a good relationship with financial institutions and customers. Old firms have also established the reputation in the markets. Therefore, firm age often represents the experience of the firms in the industry, which can be the influential factor for firm success.

Training for employees is building the human capital of a firm at the technical level, which expect to impact performance. When employees' skills are required for specific tasks, products and projects, they become "dedicated skills" through learning in different forms, strategic combinations of dedicated skills eventually become "core skills" (Kamoche, 1996). Core skills can be used in new products, markets dedicated skills and innovation.

Traditionally, training was emphasized in human capital theory (Schultz, 1960), which suggested that investment of firm in skill development can improve productivity and efficiency of employees, with the costs of training such as paying an instructor, buying materials and downtime can be offset. Training is a crucial factor to improve skills and knowledge of the employees. The policy of Motorola's CEO, for example, has a five-year training plan and emphasizes that all employees are required to upgrade their skills if the company wants to survive in the long-term. Thus, Motorola has increased investments substantially in annual training budget from 7 to 120 million US dollars (Wiggenhorn, 1990).

In addition, capabilities of employees have been developed by firms' investing in different types of training. Building employees' know-how has been ranked by chief executives as of the most crucial contributor to business success (Hall, 1993). Human resource management strategy can be developing employees through training, which is part of firm investment in human capital in order to realize the potential skills and knowledge of its employees.

The concept of RBV also suggests that developing existing employees can be with far less costs than if a firm acquires the specific-skilled people from the external labor market. Internal capacity building policies can create the strength of human capital that is specific to a firm. In turn, it enhances competitive advantage for the firms. Employees are internally developed to achieve productivity outcomes, which do not need making investment in human "strategic factors" in an open competitive market (Barney, 1986a).

Finally, firm-sponsored training is to enhance the firm specificity of employee skills that can prevent other firms to deploy these trained employees in equally productive purposes (Koch \& McGrath, 1996). As the knowledge and skills of trained employees are specific to serve current firms, they can prevent new firms to use full capacity of these employees. In the case of the employees, they are hired away by other firms. However, the retention of employees with firm-specific skills is needed by the firm through promotion the trained employees as a critical mechanism for filling vacancies. If a firm invests in training but it fails to promote these employees, it is seen to be failing to capitalize on its investment (Koch \& McGrath, 1996). 


\section{Research methodology}

\subsection{Sample and data collection}

The study uses secondary data that are supported by Enterprises Baseline Survey (EBS) in 2007 from Germany Agency for Technical Cooperation (GTZ). The enterprise sample selected only the enterprises that are formally registered. Only questionnaires which are responded from entrepreneurs are analyzed. The sample size is 378 Lao SMEs $(n=378)$ that covered five provinces of which four belong to the economically dynamic provinces in Lao PDR: Vientiane capital, Champasack, Luang Prabang, Savanakhet and one rural province is Luang Namtha.

\subsection{Measurement}

There are five independent variables: education of entrepreneurs, business development services for entrepreneurs, training at starting business for entrepreneurs, training for entrepreneurs, experience of entrepreneurs, one dependent variable (performance), and three control variables (firm size, firm age and training for employees). Each of these variables is explained below on how they are measured.

Education of entrepreneurs is measured by ordinal numbers from 1 to 11 corresponding to the level of education of owner/managers from the lowest to the highest level: no schooling, some primary school, completed primary school, some lower secondary school, completed lower secondary school, some upper secondary school, completed upper school, vocational school, technical school, higher (under graduated) and post graduated.

Business development services for entrepreneurs: Whether the question is the owner/managers of a firm received any advice for the development of his/her business or not. This variable is measured as dummy variable.

Training at starting business for entrepreneurs: Whether the question asked is entrepreneurs of a firm received training at starting business or not. This variable is measured as a dummy variable. If the respondent chose "yes", then the next question is described by indicating the kind of management training, including health and safety, cost calculation, business management, accounting, marketing, law and regulations, quality management, business finance and others.

Training for entrepreneurs: Whether the question is any training was received since they started their business or not. If the respondent chose "yes", then the next question asked describes the kind of management training, including health and safety, cost calculation, business management, accounting, marketing, law and regulations, quality management, business finance and others. Therefore, this variable is measured by an aggregated number of types of training.

Experience of entrepreneurs is measured by the age of owner/managers that subtracted the total years in the schools and universities. Because of limitation on data set, experience cannot be specified beyond working experience of owner/managers, which have accumulated from the past and current work after completing schools and universities.

Performance is a dependent variable in this study, which is measured by ordinal numbers from 1 to 5 corresponding to a level of annual turnover or sales (as stated to tax office) from the lowest to the highest level: less than 100 Million Kip, 200-400 Million Kip, 400-700 Million Kip, 700-1,000 Million Kip, and more than 1,000 Million Kip. One US dollar is equivalent to 9,696 Lao Kip during the survey period.

Firm size, firm age and training for employees are used as control variables. Firm size is measured by the total number of current full-time employees. According to Prime Ministerial Decree No.42 (2004), the Lao PDR defines a micro firm as consisting of 1 to 2 employees, a small firm as 3 to 19 employees, a medium firm as 20 to 
99 employees and a large firm as 100 employees or more. Firm age is the number of years since SMEs were established until 2007, which can represent an industry experience for firms. Training for employees: Whether the question is the employees of firm received training at the start of business or not. If the respondent chose "yes", then the next question asked describes the kind of management training, including customer services, accounting, record booking, operation of machinery and tools, computer, documentation and filing and others. Thus, this variable is measured by an aggregated number of types of training.

\section{Data analysis and discussion}

\subsection{Models}

The multiple regression technique is used as the analytical method in this research. The regression analysis is used to examine the relationship between dependent variable and three control variables (firm size, firm age and training for employees) and five independent variables (education, business development services, training at starting business, training for entrepreneurs and experience of entrepreneurs). The research model and hypotheses are tested by using multiple regression models for analysis as follows:

$$
\text { PER }=\alpha 0+\sum_{i=}^{5} \beta_{i} x_{i}+\sum_{j=1}^{3} \gamma_{j} z_{j}+e
$$

Where, $y_{i}$ is performance (PER), and $x_{i}$ are five independent variables, namely, education (EDU), business development services (BDS), training at starting business (TSB), training for entrepreneurs (TRNFE), and experience of entrepreneurs (EXP). Three control variables $\left(z_{j}\right)$ include firm size (FS), firm age (FA), and training for employees (TRNE). The multiple regression models are used to answer five hypotheses on whether the human resources are positively associated with business performance in Lao SMEs.

\subsection{Analysis results}

Table 1 displays the sample characteristics. The distribution of firms by gender shows that 218 firms (58 percent) were operated by male, compared to 160 (42 percent) operated by female. About 70 percent of firm age is less than one year to 10 years old and 26 percent is between 11 to 20 years, respectively. The share of small firms represents 81 percent while the medium firms are only 19 percent in the sample. For the education of owner/managers, it presents different education levels. Two groups of education levels of owner/managers show the similarity proportion such as completed upper secondary school and vocational school. Owner/managers who completed the under graduate represents 25 percent while the smallest percentage of owner/managers had no school (1.32 percent).

Table 2 presents the means, standard deviations and Pearson correlation matrix of the research variables. To verify the validity of the models, it tests for multicollinearity among independent variables by calculating variance inflation factor (VIF) (Kleinbaum, et al., 1998) in regression models. The VIF for all research variables found to be between 1.14 to 1.39 , which is far below the VIF of 10 that Kennedy suggests is indicative of "harmful collinearity" (Kennedy, 1992, p. 183), it suggests that there is no problematic multicollinearity presented in the model as the results of any subsequent statistical tests ${ }^{2}$ (in Table 3). In other words, the VIF statistics for each explanatory variable were at only above 1.0 (Neter, et al., 1985), providing evidence that no variable caused excessive influence on the results because of multicolinearity (Sharfman \& Fernando, 2008).

\footnotetext{
2 The VIF is calculated as $1 /(1-\mathrm{r} 2)$ (Newbert, 2008, p. 756).
} 
Table 1 Sample characteristics

\begin{tabular}{|c|c|c|}
\hline & Frequency & Percent $(\%)$ \\
\hline \multicolumn{3}{|l|}{ Gender } \\
\hline Male & 218 & 57.67 \\
\hline Female & 160 & 42.33 \\
\hline \multicolumn{3}{|l|}{ Firm age } \\
\hline $1>-10$ years old & 264 & 69.84 \\
\hline 11-20 years old & 99 & 26.19 \\
\hline 21-30 years old & 10 & 2.65 \\
\hline $31-40$ years old & 3 & 0.79 \\
\hline 41-56 years old & 2 & 0.53 \\
\hline \multicolumn{3}{|l|}{ Firm size (No. of Employees) } \\
\hline Small: 3-19 & 305 & 80.69 \\
\hline Medium: 20-99 & 73 & 19.31 \\
\hline \multicolumn{3}{|l|}{ Education } \\
\hline No schooling (0 year) & 5 & 1.32 \\
\hline Some primary school (2.5 years) & 7 & 1.85 \\
\hline Completed primary school (5 years) & 29 & 7.67 \\
\hline Some lower secondary school (1.5 years) & 13 & 3.44 \\
\hline Completed lower secondary School (3 years) & 35 & 9.26 \\
\hline Some upper secondary school (1.5 years) & 5 & 1.32 \\
\hline Completed upper secondary school (3 years) & 71 & 18.78 \\
\hline Vocational (2 years) & 83 & 21.96 \\
\hline Technical (3 years) & 11 & 2.91 \\
\hline Higher (Under graduated) (4 years) & 96 & 25.40 \\
\hline Post graduated (2 years) & 23 & 6.08 \\
\hline
\end{tabular}

Table 2 Means, standard deviation and correlations

\begin{tabular}{|c|c|c|c|c|c|c|c|c|c|c|c|}
\hline Variables & Mean & S.D & 1 & 2 & 3 & 4 & 5 & 6 & 7 & 8 & 9 \\
\hline PER & 2.24 & 1.61 & 1 & & & & & & & & \\
\hline EDU & 7.50 & 2.49 & $0.22 * *$ & 1 & & & & & & & \\
\hline BDS & 0.45 & 0.50 & $0.25^{* *}$ & $0.17 * *$ & 1 & & & & & & \\
\hline TSB & 0.39 & 0.49 & $0.21 * *$ & $0.22 * *$ & $0.19 * *$ & 1 & & & & & \\
\hline TRNFE & 0.81 & 0.83 & 0.02 & $0.16^{* *}$ & $0.19 * *$ & $0.11^{*}$ & 1 & & & & \\
\hline EXP & 33.07 & 11.69 & $0.16^{* *}$ & $-0.33^{* *}$ & 0.05 & 0.08 & $-0.14^{*}$ & 1 & & & \\
\hline FS & 13.37 & 14.93 & $0.52 * *$ & $0.25^{* *}$ & $0.19^{* *}$ & $0.23 * *$ & 0.06 & $0.11^{*}$ & 1 & & \\
\hline FA & 8.40 & 6.87 & $0.12 *$ & -0.07 & -0.053 & -0.07 & -0.09 & $0.34 * *$ & $0.11^{*}$ & 1 & \\
\hline TRNE & 1.46 & 1.25 & $0.24 * *$ & $0.12^{*}$ & $0.27 * *$ & $0.17 * *$ & $0.26^{* *}$ & 0.08 & $0.18^{* *}$ & -0.01 & 1 \\
\hline
\end{tabular}

Notes: ${ }^{*}$ Correlation is significant at the 0.01 level $\& * 0.05$ level (2-tailed).

In Table 3, the model shows that $F$-statistic is significantly suggesting that the model not only fits the data well, but also indicates the robust relationship between explanatory variables and dependent variable. The results also show that the model explains a considerable amount of the explained variance in performance $\left(\mathrm{R}^{2}=34 \%\right.$ and adjusted $\mathrm{R}^{2}=32 \%$ ). 
Table 3 Multiple regression results

\begin{tabular}{lccccc}
\hline \multicolumn{1}{c}{ Performance (PER) } & & & & \\
\hline & Coefficients & Std. Error & Beta & $\mathrm{t}$ & VIF \\
\hline (Constant) & 0.092 & 0.36 & & 0.25 & \\
Education of entrepreneurs (EDU) & 0.079 & 0.03 & 0.12 & $2.50^{* *}$ & 1.32 \\
Business development services for entrepreneurs (BDS) & 0.40 & 0.15 & 0.12 & $2.70^{* * *}$ & 1.16 \\
Training at starting business for entrepreneurs (TSB) & 0.16 & 0.15 & 0.05 & 1.03 & 1.15 \\
Training for entrepreneurs (TRNFE) & -0.13 & 0.09 & -0.06 & -1.43 & 1.14 \\
Experience of entrepreneurs (EXP) & 0.01 & 0.01 & 0.11 & $2.17^{* *}$ & 1.39 \\
Firm size (FS & 0.04 & 0.00 & 0.42 & $9.01^{* * *}$ & 1.19 \\
Firm age (FA) & 0.01 & 0.01 & 0.05 & 1.13 & 1.17 \\
Training for employees (TRNE) & 0.16 & 0.06 & 0.12 & $2.67^{* * *}$ & 1.17 \\
$\mathrm{R}^{2}$ & 0.34 & & & & \\
Adjusted R & & & & & \\
F-Statistics & 0.32 & & & & \\
Durbin-Watson & $23.33^{* * *}$ & & & & \\
$\mathrm{n}$ & 1.83 & & & & \\
\hline
\end{tabular}

Notes: ${ }^{*} \mathrm{p} \leq 0.10 ;{ }^{* *} \mathrm{p} \leq 0.05 ;{ }^{* * *} \mathrm{p} \leq 0.001$.

\subsubsection{Human resources and performance}

Human resource variables were partially supported in this analysis, particularly, the education of entrepreneurs and business development services for entrepreneurs, which were associated with firm performance (in Table 3), whereas the training at starting business for entrepreneurs received no support.

Education of entrepreneurs is positively significant at 5 percent with firm performance. This might suggest that education of entrepreneurs is a powerful tool for business success, because it represents the knowledge bases and skills of entrepreneurs. Education of entrepreneurs indicates the absorptive capacity for the firms. Higher education levels of entrepreneurs indicate higher human capital of the firms, which can contribute to firm performance. Psychologically, the collection of knowledge and prior-qualification can also increase the confidence of entrepreneurs. The finding is also supported in the literature (Box, et al., 1993; Brush \& Hisrich, 1991). Therefore, hypothesis 1 received support.

Business development services (BDS) for entrepreneurs were statistically significant at 1 percent. The finding suggests that BDS provide meaningful knowledge and skills for entrepreneurs to improve business performance. BDS are designed not only to support the operational services but also they can improve strategic services. Operational services and strategic services aim to improve short-term performance. Therefore, firms had obtained BDS, which assist them to boost sales and ultimately to affect the overall firm performance. Hence, hypothesis 2 was supported.

Training for entrepreneurs at starting business (TSB) was not significant. Although, TSB is expected to achieve different types of business skills in order to improve business performance. One possible interpretation is that failure to find a significant relationship between TSB and performance was probably due to inappropriate contents of training. The actual contents may not be practical for the firms. Therefore, hypothesis 3 was not supported.

\subsubsection{Human resource development and performance}


Human resource development variable did not influence firm performance (in Table 3). The training for entrepreneurs was insignificant. The finding is surprising but it is because the training for entrepreneurs in SMEs expects to have some impact on firm success. Investment in human capital is vital particularly in the leadership level. Perhaps the contents of training are irrelevant for specific needs of entrepreneurs. The entrepreneurs may need specific knowledge and skills for specific purposes. Relevant specific knowledge and skills of entrepreneurs can have more direct impact on performance. Thus, hypothesis 4 was not supported.

\subsubsection{Working experience of human resources and performance}

The working experience of entrepreneurs was found to have a positive impact on firm performance that was statistically significant at 5 percent (in Table 3). This suggests that previous experience of entrepreneurs collected from the past events and current work in many types of skills and knowledge can enhance firm performance. As experience of entrepreneurs involved not only past working experiences but also on-the-job-training, which can increase skills and knowledge including firm specific ones so that it is not easy for rivals to exactly imitate. This can lead to improve firm performance. The result was also supported by earlier researches by Yusuf (1995), Box, et al (1993) and Schutjens \& Wever (2000), wherein previous experiences of entrepreneurs was correlated with performance. Hence, the result provided support for hypothesis 5.

The parameter estimates for the control variables show that firm size is statistically significant at 1 percent level. The results suggest that firm size positively affect firm performance. The larger firm performs better than the smaller one. The influential training for employees is also found to be statistically significant at 1 percent. Perhaps, firms emphasize more on human resources at the practical level, which can have immediate impact on firm performance. The employees are involved in more specific tasks at the practical level and thus it is worthwhile for firms to train them to achieve specific purposes in line with the firms' objectives. However, the firm age had no influence on performance. That means in the case of Lao SMEs, an older firm does not necessarily perform better than a young one.

\section{Conclusion}

\subsection{Finding and conclusion}

The impact of human resources on performance had mixed results for this paper in the case of Lao SMEs. Overall, the useful variables in explaining performance in Lao SMEs were the education of entrepreneurs (H1), business development services for entrepreneurs (H2), and experience of entrepreneurs (H5). The findings highlight that human resources with human capital are very important components at the beginning of business. The human capital is inherited by entrepreneurs in terms of knowledge and skills that are strategic resources for the firms to improve the productivity and business operations. Whereas training at starting business (H3) and training for entrepreneurs (H4) received no support. In both cases, training at the start of business and after starting the business for entrepreneurs in Lao SMEs are insignificant to firm performance. Perhaps, in these cases the contents of training obtained by entrepreneurs may not be practical for the firms, so that firms cannot maximize the potential return on their investments in the human capital.

\subsection{Policy implications}

This research can provide some policy implications to both policy maker (i.e. government) and implementer (i.e. SMEs). The policy maker can assist the SMEs through a policy implementation, rules and regulations, which can improve the performance of SMEs. Some factors are needed for continuous support by the government. The 
government should keep investing in entrepreneurs for the country by improving high quality entrepreneurs in the different fields availability for firms. Allocating and seeking for the fund to support human resource development in various means such as training, business development services, mentoring, and consultations for business sector are important for firm's success. It is also important for the government to improve the training contents in colleges and universities, which need to be relevant and useful for entrepreneurs in order to achieve the optimum return on investment in human capital for private firms.

For SMEs, a high education level and the working experiences of entrepreneurs are encouraged to be emphasized as they are vital to firm's success. They are also encouraged to continually invest in human capital through human resource development and obtaining business development services in order to achieve superior performance. In addition, careful selections for training contents for entrepreneurs are needed to maximize the potential return on investments in human capital for the firms regarding training for entrepreneurs.

\subsection{Research limitations and future research}

The secondary data have some limitations for selecting theoretical meaningful variables. Future studies can look at human resources from different perspectives by including different human resource variables. Apart from the limitations of variables in the study, the authors realize that other factors could also affect business performance in the case of Lao SMEs.

\section{References:}

Aharoni, Y.. (1993). In search for the unique: Can firm-specific advantage be evaluated?. Journal of Management Studies, 30(1), 31-49.

Amit, R. \& Schoemaker, P. J. H.. (1993). Strategic assets and organizational rent. Strategic Management Journal, 14, 33-46.

Andrews, K. R.. (1980). The concept of corporate strategy. Homewood: Ill, Richard D, Irwin.

Barney, J. B.. (1986a). Strategic factor markets: expectations, luck, and business strategy. Management Science, 32(10), $1231-1241$.

Barney, J. B.. (1991). Firm resources and sustained competitive advantage. Journal of Management, 17(1), 99-120.

Barney, J. B. \& Arikan, A.. (2001). Resource-based view: origins and implications. In: Hitt M, Freeman R \& Harrison J.. (Eds.), The Blackwell handbook of strategic management. Malden: Blackwell, MA.

Becker, G. S.. (1975). Human capital. New York: National Bureau of Research.

Becker, G. S.. (1964). Human capital. New York: National Bureau for Economic Research.

Becker, G. S.. (1976). The economic approach to human behavior. Chicago: University of Chicago Press.

Bishop, J. H.. (1991). The impact of previous training in schools and on job on productivity, require OJT, and turnover of new hires. Center for Advanced Human Resource Studies, Cornell University. Cited in Cappelli and Singh, 1992. (Unpublished manuscript)

Box, T. M., M. A. White \& Barr, S. H.. (1993). A contingency model of new manufacturing firm performance. Entrepreneurship Theory and Practice, 18(2), 31-45.

Boxall, P. F.. (1996). The strategic HRM debate and the resource-based view of the firm. Human Resource Management Journal, $6(3), 59-75$.

Brush, C. G. \& Hisrish, R. D.. (1991). Antecedent influences on women-owned business. Journal of Management Psychology, 6(2), 9-16.

Cappelli, P. \& Singh, H.. (1992). Integrating strategic human resources and strategic management. In: Lewin, D., Mitchell, O. S. \& Sherer, P. D.. (Eds.), Research frontiers in industrial relations and human resources. Win: Industrial Relations Research Association.

Casson, M.. (1982c). The entrepreneur: An economic theory. Martin Robertson: Oxford.

Castanias, R. P. \& Helfat, C. E.. (1991). Managerial resources and rents. Journal of Management, 17, 155-177.

Chandy, R. K. \& Tellis, G. J.. (2000). The incumbent's curse? Incumbency, size, and radical product innovation. Journal of Marketing, $13,1-17$.

Collins-Dodd, C., Cordon, I.M. \& Smart, C.. (2004). Further evidence on the role of gender in financial performance. Journal of Small Business Management, 42(4), 395-417. 
Cooper, A. C.. (1981). Strategic management: New ventures and business performance. Long Range Planning, 14(5), 39-45.

Cooper, A. C., Gimeno-Gascon, F. J. \& Woo, C. Y.. (1994). Initial human and financial capital as predictors of new venture performance. Journal of Business Venturing, 9, 371-395.

Crook, T. S., Ketchen J. R., D. J., Combs, J. G. \& Todd, S.. (2008). Strategic resources and performance: A meta-analysis. Strategic Management Journal, Early View P n/a.

Daily, C. M., Certo, S. T. \& Dalton, D. R.. (1999). A decade of corporate women: Some progress in the boardroom, non in the executive suite. Strategic Management Journal, 20(1), 93-100.

Danneels, E.. (2008). Organizational antecedents of second-order competences. Strategic Management Journal, 29, 519-543.

Dass, P. (2000). Relationship of firm size, initial diversification, and internationalization with strategic change. Journal of Business Research, 48(2), 135-146.

Dess, G. (1987). Consensus in the strategy formulation and organizational performance: Competitors in a fragmented industry. Strategic Management Journal, 8(3), 259-277.

Dess, G. G. \& Robinson J. R., R. B.. (1984). Measuring organizational performance in the absence of objective measures: The case of the privately-held firm and conglomerates business unit. Strategic Management Journal, 5, 265-273.

Dierickx, I. \& Cool, K.. (1989). Asset stock accumulation and sustainability of competitive advantage. Management Science, 35(12), 1504-1511.

Duncan, G. \& Hoffman, S.. (1981). The incidence and wage effects of over education. Economics of Education Review, 1(1), 75-86.

Fahy, J. \& Smithee, A.. (1999). Strategic marketing and the resource based view of the firm. Academy of Marketing Science Review, $1,1-13$.

Finkelstein, S. \& Hambrick, D. C.. (1996). Strategic leadership. St. Paul: West.

Flamholtz, E. G. \& Lacey, J. M.. (1981). Personnel management, human capital theory, and human resource accounting. Los Angeles: Institute of Industrial Relations, University of California.

Ghemawat, P.. (1986). Sustainable advantage. Harvard Business Review, 64(6), 53-58.

Goerzen, A.. (2007). Alliance networks and firm performance: The impact of repeated partnerships. Strategic Management Journal, 28(5), 487-509.

Grant, R. M.. (1996). Toward a knowledge-based theory of the firm. Strategic Management Journal, 17(Winter Special Issue), 109-122.

Grant, R. M.. (2002). Contemporary strategy analysis: concepts, techniques, applications (4th ed.). Massachusetts: Blackwell.

Hall, R.. (1993). A framework linking intangible resources and capabilities to sustainable competitive advantage. Strategic Management Journal, 14, 607-618.

Hambrick, D. C. \& Mason, P. A.. (1984). Upper echelons: The organization as a reflection of its top manager. Academy of Management Review, 9(2), 193-206.

Hatch, N. W. \& Dyer, J. H.. (2004). Human capital and learning as a sources of sustainable competitive advantage. Strategic Management Journal, 25, 1155-1178.

Hoopes, D. G., Madsen, T. L. \& Walker, G. (2003, October). Guest editors' introduction to the special issue: Why is there a resource-base perspective? Toward a theory of competitive heterogeneity. Strategic Management Journal, 24(Special Issue), 889-902.

Huselid, M. A.. (1995). The impact of human resource: Management practices on turnover, productivity and corporate financial performance. Academy of Management Journal, 38, 635-672.

Jacoby, D.. (1991). Legal foundations of human capital markets. Industrial Relations, 30(2), 229-250.

Kamoche, K.. (1996). Strategic human resource management within a resource-capability view of the firm. Journal of Management Studies, 33(2), 213-233.

Kanter, R. M.. (1988). When a thousand flowers bloom: Structural, collective, and social conditions for innovation in organizations. In: Staw, B. M. \& Cummings, L. L. (Eds.), Research in organizational behavior. Greenwich, CT: JAI Press.

Kennedy, P.. (1992). A guide to econometrics. Cambridge: MIT Press, MA.

Kennedy, R. M.. (2000). Sustainability in business development services: Operation of Romanian business centers. In: P. Scholtes, C. Sonesson \& M. Onita. (Eds.). Vienna: UNIDO.

Kerr, J. \& Slocum, J. W.. (1987). Managing corporate culture through reward systems. Academy of Management Executive, 1(2), 99-108.

Ketchen, J. R D. J., Hult, G. T. M. \& Slater, S. F.. (2007). Toward greater understanding of market orientation and resource-based view. Strategic Management Journal, 25(2), 961-964. 
Klein, J. A., Edge, G. \& Kass, T.. (1991). Skill-based competition. Journal of General Management, 16, 1-15.

Kleinbaum, D. G., Kupper, L. L., Muller, K. E. \& Nizam, K. E.. (1998). Applied regression analysis and other multivariable methods. Pacific Grove, CA: Duxberry Press.

Klien, B., Crawford, R. G. \& Alchain, A. A.. (1978). Vertical integration, appropriable rents, and the competitive contracting process. Journal of Law and Economics, 21, 297-326.

Koch, M. J. \& McCrath, R. G.. (1996). Improving labor productivity: Human resource management policies do matter. Strategic Management Journal, 17, 335-354.

Lahteenmaki, S. \& Paalumaki, A.. (1993). The retraining and mobility motivations of key personnel: Dependencies in the finish business environment. International Journal of Human Resource Management, 4, 377-406.

Lawrence, P. \& Lorsch, J.. (1967). Organization and environment: Managing differentiation and integration. Home Wood, IL: Irwin.

Mahoney, J. T.. (1992). The choice of organization form: Vertical financial ownership versus other method of integration. Strategic Management Journal, 13(8), 559-584.

Mahoney, J. T. \& Pandian, J. R.. (1992). The resource-based view within the conversation of strategic management. Strategic Management Journal, 13, 363-380.

McConnell, R. C. \& Bruc, S. L.. (1995). Contemporary labor economics. Singapore: McGraw-Hill.

Mukhtar, S. (2002). Differences in male and female management characteristics: A study of owner-manager businesses. Small Business Economics, 18, 289-311.

Neter, J., Wasserman, W. \& Kuter, M. H.. (1985). Applied linear statistical models. Home Wood, IL: Irwin.

Ng Wai-Kit, P., Lau, C. M. \& Nyaw, M. K.. (2007). The effect of trust on international joint venture performance in China. Journal of International Management, 13, 430-448.

Newbert, S. L.. (2008). Value, rareness, competitive advantage, and performance. Strategic Management Journal, 29(7), $745-768$.

O’Neill, H. M. \& Duker, J.. (1986). Survival and failure in small business. Journal of Small Business Management, 24(1), 30-37.

Oliver, C.. (1997). Sustainable competitive advantage: Combining institutional and resource-base views. Strategic Management Journal, 18(9), 697-713.

Parnes, H. S.. (1984). People power. Beverly Hills, CA: Sage Publications.

Pennings, J. M., Lee, K. \& Witteloostuijn, A. V.. (1998). Human capital, social capital and firm dissolution. Academy of Management Journal, 41(4), 425-440.

Penrose, E.. (1995). The theory of the growth of the firm (3rd ed.). New York: Oxford University Press.

Peteraf, M. A.. (1993). The cornerstones of competitive advantage: A resource-based view. Strategic Management Journal, 14, 179-191.

Peteraf, M. A. \& Arney, J. B. (2003). Unraveling the resource-base tangle. Managerial and Decision Economics, 24(4), 309-323.

Pfeffer, J. (1994). Competitive advantage through people. Boston: Harvard Business School Press.

Powell, T. C. (1992a). Organizational alignment as competitive advantage. Strategic Management Journal, 13(2), 119-134.

Powell, T. C. \& Dent-Micallef, A. (1997). Information technology as competitive advantage: The role of human, business, and technology resources. Strategic Management Journal, 18(5), 375-405.

Prime Minister. (2004, April 20th). Decree No.42 on the promotion of small-and medium-sized enterprises. Vientiane.

Robinson, R. \& Pearce, J. (1988). Planned patterns of strategic behavior and their relationship to business unit performance. Strategic Management Journal, 9(1), 43-60.

Rosa, P., Carter, S. \& Hamilton, D.. (1996). Gender as a determinant of small business performance: Insights from and British study. Small Business Economics, 8, 463-478.

Rumberger, R. W.. (1987). The impact of surplus schooling on productivity and earnings. Journal of Human Resources, 22(1), 24-50.

Sapienza, H. J., Smith, K. G. \& Gannon, M. J.. (1988, Winter). Using subjective evaluations of organizational performance in small business research. American Journal of Small Business, 45-53.

Schultz, T. W.. (1960). The formation of human capital by education. Journal of Political Economy, 68, 571-583.

Schutjens, V. A. J. \& Wever, E.. (2000). Determinants of new firm success. Papers in Regional Science, 79, 135-159.

Sharfman, M. P. \& Fernando, C. S.. (2008). Environment risk management and the cost of capital. Strategic Management Journal, 29, 569-592.

Sheridan, J. E.. (1992). Organizational culture and employee retention. Academy of Management Journal, 35(5), 1036-1056.

Snell, S. A. \& Dean, J. W.. (1992). Integrated manufacturing and human resource management: A human capital perspective. Academy of Management Journal, 35(3), 467-504.

Spanos, Y. E. \& Lioukas, S.. (2001). An examination into the causal logic of rent generation: Contrasting porter's competitive 
strategy framework and the resource-based perspective. Strategic Management Journal, 22(10), 907-934.

Steffy, B. D. \& Maurer, S. D.. (1988). Conceptualizing and measuring the economic effectiveness of human resource activities. Academy of Management Review, 13(2), 271-286.

Steiner, M. P. \& Solem, O.. (1988). Factors for success in small manufacturing firms. Journal of Small Business Management, 26(1), 51-56.

Tanburn, J., G. Trah \& Hallberg, K.. (2001). Business development services for small enterprises: Guiding principles for donor intervention. Washington: SME Dept, World Bank.

Thompson, J. D.. (1967). Organizations in action. New York: McGraw-Hill.

Tsang, M. C.. (1987). The impact of underutilization of education on productivity: A case study of the U.S. Bell companies. Economics of Education Review, 6, 239-254.

Venkatraman, N. \& Ramanujam, V.. (1986). Measurement of business performance in strategy research: A comparison of approaches. Academy of Management Review, 11, 801-814.

Watson, J.. (2002). Comparing the performance of male and female-controlled businesses: Retailing outputs to inputs. Entrepreneurship Theory and Practice, 91-100.

Wernerfelt, B.. (1984). A resource-based view of the firm. Strategic Management Journal, 5, 171-180.

Wernerfelt, B.. (1995). The resource-based view of the firm: Ten years after. Strategic Management Journal, 16, 171-174.

Wiggenhorn, W.. (1990). Motorola U: When training becomes an education. Harvard Business Review, 68(4), 71-83.

Winter, S.. (1987). Knowledge and competence as strategic assets, In: D. J. Teece. (Ed.), The competitive challenge. Ballinger: Cambridge, MA.

Wright, P. M., McCormahan, G. C. \& McWilliams, A.. (1994). Human resources and sustained competitive advantage: A resource-based perspective. International Journal of Human Resource Management, 5(2), 301-326.

Yusuf, A.. (1995). Critical success factors for small business: Perceptions of South Pacific entrepreneurs. Journal of Small Business Management, 32(3), 68-73.

(Edited by Annie and Chris)

\section{(continued from Page 12)}

\section{References:}

Beckmann M. \& Thisse J-.F.. (1986). The location of production activities. In: Nijkamp P. (Ed.), Handbook of regional and urban economics (Vol.1). North-Holland.

Chamberlin E. N.. (1933). The theory of monopolistic competition. Mass: Harward Univ. Press.

Fujita M., Krugman P. \& Venables A.. (1999). The spatial economy: Cities, regions and international trade. USA: MIT Press.

Henrich J., Boyd R., Bowles S., et al.. (2001). Economic man in cross-cultural perspective: Behavioral experiments in fifteen small-scale societies. Santa Fe Institute, Working Paper 01-11-063.

Hotelling H.. (1929). Stability in competition. Econ. J., 39, 41-57.

Ladd H.. (1992). Population growth, density and the costs of providing public services. Urban Studies, 29(2), 273-275.

Monnensland J. \& Westlund H.. (1999). Cross border cooperation in low population density areas. ERSA Conference, Dublin.

Westund H.. (1999). An interaction-cost perspective of networks and territory. Annals of Regional Science, 33(1).

Wirth L.. (1969). Urbanism as a way of life. In: Richard Sennett. (Ed.), Classical essays on the culture of cities. N.Y.: Appleton-Centry-Crofts, 67-83. (Original work published 1938).

Yegorov Y.. (1997). Self-organization of spatial infrastructure. Santa Fe Institute. Working Paper No.97-06-055, 18.

Yegorov Y.. (2000). Evolution of trust in societies. Proceedings of the 4th Japan-Australia Joint Workshop on Intelligent and Evolutionary Systems. Hayama, Japan, 185-192.

Yegorov Y. (2005a). Role of density and field in spatial economics. In: Yee Lawrence. (Ed.), Contemporary issues in urban and regional economics. N.Y.: Nova Science Publishers, 55-78.

Yegorov Y.. (2005b). Dynamically sustainable economic equilibria as self-organized atomic structures. In: M. Salzano \& A. Kirman. (Eds.), Economics: Complex windows. Italy: Springer-Verlag Italia, 187-199.

Yegorov Y.. (2007a). Econo-physics: A perspective of matching two sciences. Evol. Inst. Econ. Rev., 4(1), 143-170.

Yegorov Y.. (2007b). Dynamics of spatial infrastructure with application to gas and forest. The 6th Conference on Applied Infrastructure Research, TU Berlin, Germany. 